\title{
Kurva Laktasi Induk Domba Jonggol (Domba Ekor Tipis) Berdasarkan Umur Induk yang Dipelihara dengan Sistem Penggembalaan
}

\author{
(Lactation Curve of Jonggol Ewes (Thin Tail Sheep) on Ewe Age Were Reared Grazing \\ System)
}

Jarmuji

\author{
Jurusan Peternakan, Fakultas Pertanian Universitas Bengkulu \\ JL. Kandang Limun, Bengkulu 38125 \\ Email: jarmuji_78@yahoo.com
}

\begin{abstract}
The objectives of this research were to know the effect of ewe's age on curve of milk yield reared on grazing. This research was done in The Jonggol Animal Science Teaching, and Research Unit (JASTRU) located in Singasari Village, Jonggol, Bogor district. As many 100 local sheep comprises of pregnant and lactating ewes on average 1-4 years old were used in this research. The sheeps were grazed from 9 a.m. to 4 p.m. and housed on night. The result showed that ewe's age different effect its of curve milk yield.Lactation peak is expected within 1-2 weeks of lambing, followedby a decreasing phase to the 16 weeks. Decreace of theewes 1 year age showed is not stable if comparation the ewes 3-4 year age.
\end{abstract}

Key words : ewes, curve milk yield, grazing system.

\section{PENDAHULUAN}

Domba lokal merupakan salah satu sumber daya genetik ternak yang berpotensi dikembangkan dalam penyediaan daging nasional. Domba lokal memiliki beberapa keunggulan diantaranya kemampuan dalam melahirkan anak kembar dua ekor atau lebih, umur dewasa kelamin relatif cepat serta tidak mengenal musim kawin sehingga dapat beranak sepanjang tahun. Domba lokal pada dasarnya digolongkan menjadi dua yaitu Domba Ekor Tipis (DET) dan Domba Ekor Gemuk (DEG). Namun di beberapa daerah tempat domba berkembang dengan lingkungan yang berbeda, seringkali domba lokal tersebut dikelompokan galur tersendiri. Domba lokal yang berkembang di Indonesia antara lain domba jonggol (DET), domba priangan di Garut (DET), domba indramayu (DEG), domba madura (DEG), domba donggala (DEG), Domba Rote (DEG), domba kisar (DEG) dan domba sumbawa (DEG) (Sumantri et al., 2007)

Domba jonggol (DET)merupakan hasil persilangan domba ekor tipis dengan domba garut yang berkembang sejak tahun 1980 dan telah mengalami seleksi secara alami pada lingkungan panas dan kering di lokasi Unit Pendidikan, Penelitian dan Peternakan Jonggol (UP3J), Kabupaten Bogor. Domba jonggol memiliki ciri berekor tipis, pendek dan tidak berlemak, telinga berukuran kecil sampai medium, warna bulu putih belang hitam dan banyak bercak belang hitam disekitar mata dan 
hidung, domba jantan bertanduk sedangkan domba betina tidak bertanduk (Jarmuji, 2008).

Domba jonggol (DET)memiliki siklus reproduksi yang cepat, dengan jarak kelahiran delapan bulan maka dalam dua tahun seekor induk domba sedikitnya menghasilkan tiga ekor anak pada kelahiran tunggal atau 1,5 ekor anak per induk pertahun. Namun kondisi ini masih dihadapkan pada masalah kurangnya daya tahan hidup anak domba yang dilahirkan per induk dalam mencapai usia sapih, terutama yang dilahirkan kembar dua atau lebih dengan tingkat kematian mencapai 40-85\% (Jarmuji, 2010). Angka kematian yang tinggi sebelum mencapai umur sapih ini sebagian besar disebabkan oleh kurangnya zat makanan yang disediakan oleh induk dalam bentuk air susu. Sementara anak domba sangat tergantung pada ketersediaan air susu sebagai bahan makanan dalam menopang pertumbuhan dan kehidupan sebelum ternak disapih. Produksi susu induk yang rendah juga dapat menurunkan laju pertumbuhan dan bobot sapih. Domba yang memiliki bobot sapih rendah dapat menurunkan kemampuan dalam bersaing memperoleh hijauan yang berkualitas di padang penggembalaan, sehingga pertumbuhan mencapai dewasa menjadi lambat dan menurunkan kemampuan reproduksi.
Populasi domba dapat ditingkatkan dengan cara memperbaiki produktivitas induk melalui kemampuan menghasilkan air susu pada kondisi lingkungan dan pakan yang terbatas. Kurva laktasi merupakan gambaran produksi susu harian seekor domba selama periode laktasi. Dengan mengetahui bentuk kurva produksi susu selama laktasi diharapkan dapat mengetahui kelompok induk yang lebih rentan terhadap kondisi lingkungan yang jelek dan pada akhirnya dapat melakukan manajemen pemeliharaan induk dan anak domba yang lebih baik terutama dalam memenuhi kebutuhan susu pada anak domba periode lahir sampai sapih yang dipelihara dipadang penggembalaan.

\section{MATERI DAN METODE}

Penelitian ini dilaksanakan di areal padang penggembalaan Unit Pendidikan, Penelitian dan Peternakan Jonggol Institut Pertanian Bogor (UP3J-IPB) Desa Singasari Kecamatan Jonggol Kabupaten Bogor selama 5 bulan. Sebanyak 100 ekor induk domba jonggol umur 1-4 tahun yang dipelihara di padang penggembalaan dalam kondisi buting dan laktasi. Peralatan yang diperlukan dalam penelitian kandang koloni induk yang sedang melahirkan, kandang koloni induk, kandang koloni anak, kalung nomor dan timbangan ternak merk Shalter. Pemeliharaan induk domba dilakukan dengan cara digembalakan mulai 
Kurva laktasi induk domba jonggol pukul 09.00 sampai dengan pukul 16.00 dan sore harinya ternak dimasukan ke dalam kandang.
Umur pada ternak domba dapat dilakukan dengan cara melihat pergantian gigi seri menjadi gigi tetap pada ternak (Tabel 1).

Tabel 1 Umur domba berdasarkan pergantian gigi

\begin{tabular}{|c|c|c}
\hline Umur & Pergantian Gigi seri menjadi tetap & Kode \\
\hline $1-1,5$ tahun & Sepasang gigi tetap & $\mathrm{I}_{1}$ \\
$2,0-3,0$ tahun & Dua pasang gigi tetap & $\mathrm{I}_{2}$ \\
$3,0-4,0$ tahun & Tiga pasang gigi tetap & $\mathrm{I}_{3}$ \\
$4,0-5,0$ tahun & Empat pasang gigi tetap & $\mathrm{I}_{4}$ \\
\hline
\end{tabular}

Sumber: Ensminger (2002)

\section{Pengamatan}

Produksi susu induk diukur dengan cara memisahkan anak-anak domba, kemudian sebelum dan susudah anak menyusu pada induk, terlebih dahulu dilakukan penimbangan masing-masing anak (Caja et al., 2006). Selisih bobot anak domba sebelum dan sesudah menyusu tersebut merupakan jumlah produksi susu induk. Pengukuran dilakukan pukul 23.00, 05.00, 11.00 dan 17.00 (satuan dalam gram). Produksi susu diukur setiap tiga hari sekali.

\section{Analisis statistik}

Bentuk kurva laktasi pada kelompok induk berdasarkan umur yang berbeda selama periode laktasi dilakukan dengan menggunakan analisis regresi sederhana dan analisis deskriptif.

\section{HASIL DAN PEMBAHASAN}

\section{Keadaan umum padang penggembalaan}

Secara geografis UP3J-IPB terletak antara $6^{0} \mathrm{LU}$ dan $106,53^{\circ} \mathrm{BT}$ pada ketinggian $70 \mathrm{~m}$ diatas permukaan laut. Kondisi iklim selama penelitian bulan Juni-Nopember dengan rata-rata curah hujan 182,22 mm/bulan, kelembaban $75 \%$, suhu lingkungan $25^{\circ} \mathrm{C}-34^{0} \mathrm{C}$ dan kecepatan angin rata-rata 1848,89 m/jam (UP3J, 2007). Hijauan makanan ternak yang dikembangkan di padang penggembalaan adalah rumput bachiaria humidicola. Sistem penggembalaan kontinyu mempunyai sifat sangat selektif memilih hijauan yang masih muda, sehingga pemanfaatan hijauan tidak optimum (Umberger 2001) dan menimbulkan pertumbuhan kembali rumput (regrowth) tidak merata serta interpensi gulma menjadi meningkat (Susetyo, 1980). 
Selama penelitian berlangsung produksi hijauan segar di padang penggembalaan yang dipanen umur 30 hari sebesar $350 \mathrm{~g} / \mathrm{m}^{2}$, kandungan protein dan serat kasar masing-masing sebesar 4,59\% dan $44,78 \%$. Produksi tersebut sangat rendah jika di banding dengan hasil penelitian Mansyur (2004) bahwa produksi rumput Brachiaria humidicola yang dipanen umur 30 hari dan dipupuk dengan 9 ton/ha dolomit, 2 ton/hapupuk kandang, $450 \mathrm{~kg}$ urea, $15 \mathrm{~kg}$ SP36 dan $430 \mathrm{~kg} \mathrm{KCL}$ adalah sebesar $3.260 \mathrm{~g} / \mathrm{m}^{2}$, dengan kandungan nutrisi 5,5\% protein kasar, $0,21 \%$ fospor dan $0,38 \%$ kalsium serta daya cerna bahan kering dan bahan organik masing-masing 57,23 dan 57,52\%. Skerman dan Riveros (1990) menyatakan bahwa rumput Brachiaria humidicola mengandung protein kasar sebesar 8-9\% dan serat kasar 32-35\%.

Penurunan produksi hijauan di padang penggembalaan disebabkan oleh rendahnya ketersediaan air tanah, sehingga dapat mengganggu proses metabolisme diantaranya pengurangan pembukaan stomata, laju fotosintesis dan kehilangan air dari daun (Goldsworthy dan Fisher, 1992) dan menghambat penyerapan unsur hara di dalam tanah oleh tanaman (Hardjowigeno, 2003).Menurut Minson (1990), penurunan kandungan protein kasar pada rumput selain disebabkan oleh umur tanaman, juga dapat disebabkan oleh penurunan proporsi helai daun dengan kelopak daun dan batang, dimana pada helai daun mempunyai kandungan protein yang lebih tinggi dibanding kelopak daun dan batang. Konsentrasi nitrogen pada tanaman akan menurun dengan meningkatnya umur tanaman (Whitehead, 2000). Suhu dan kelembaban udara merupakan faktor yang sangat mempengaruhi secara langsung maupun tidak langsung kandungan nutrisi hijauan di padang penggembalaan, suhu lingkungan yang tinggi dapat meningkatkan struktur material dinding sel tanaman seperti lignin dan mempercepat proses metabolisme yang dapat menurunkan ukuran ruang isi sel (Coleman dan Henry, 2002).

\section{Kurva produksi susu domba jonggol (DET)}

Kurva produksi susu pada induk $I_{1}$, $\mathrm{I}_{2}, \mathrm{I}_{3}$ dan $\mathrm{I}_{4}$ menunjukkan bahwa selama 16 minggu laktasi tidak menggambarakan kurva produksi susu yang normal (Gambar 1). Rata-rata puncak laktasi terjadi pada minggu kedua dan ketiga setelah melahirkan dan produksinya terus mengalami penurunan sampai minggu 16 (hari ke 59). Penurunan laju produksi pada induk $\mathrm{I}_{1}$ cenderung tidak stabil dan terjadi beberapa kali puncak laktasi dibanding dengan induk yang lebih tua, hal ini menunjukkan bahwa produksi susu pada $\mathrm{I}_{1}$ diduga lebih rentan terhadap perubahan 
lingkungan terutama kondisi pakan dan suhu lingkungan. Namun demikian, ratarata penurunan produksi susu setelah puncak laktasi pada $I_{1}$ jauh lebih rendah dibanding induk yang lebih tua. Rata-rata penurunan produksi susu setelah puncak laktasi $\mathrm{I}_{1} 2,21 \mathrm{~g} / \mathrm{h}$, sedangkan $\mathrm{I}_{2} 5,57 \mathrm{~g} / \mathrm{h}, \mathrm{I}_{3}$ $7,06 \mathrm{~g} / \mathrm{h}$ dan $\mathrm{I}_{4} 6,45 \mathrm{~g} / \mathrm{h}$. Hasil ini sesuai dengan pendapat Pollott dan Gootwine (2004) bahwa rata-rata penurunan produksi susu akibat dampak persistensi domba awassi pada kelahiran pertama sebesar $8,00 \mathrm{~g} / \mathrm{h}$, sedangkan pada induk umur tiga tahun mencapai sebesar $12 \mathrm{~g} / \mathrm{h}$. Menurut Borlino (2004), laju produksi susu akan meningkat sampai mencapai puncak produksi maksimum, setelah itu kemudian perlahan akan mengalami penurunan sampai akhir laktasi (periode kering). Total produksi susu selama laktasi dan bentuk kurva laktasi dipengaruhi oleh faktor lingkungan seperti manajemen pemeliharaan, bulan saat melahirkan, umur induk dan jumlah anak yang menyusui (Ruiz et al. 2000). Selanjutnya, induk bangsa domba laxta yang melahirkan anak pada bulan Nopember menunjukkan produksi susu puncak laktasi terjadi pada minggu kedua setelah melahirkan dengan puncak produksi 1,50 1/h, sedangkan induk yang melahirkan bulan Maret puncak laktasi terjadi pada minggu keempat dengan produksi 1,201/h.
Macciotta et al. (1999), melaporkanpada musim semi dimana ketersediaan pakan dengan kualitas yang baik laju produksi susu akan membentuk kurva normal dan hanya terdapat satu kali puncak laktasi, yaitu pada minggu ke-3 atau ke-4 setelah induk melahirkan. Namun pada musim panas dimana ketersediaan dan kualitas pakan rendah dan temperatur lingkungan yang tinggi menyebabkan kebutuhan induk domba tidak terpenuhi, hal ini dapat menyebabkan kurva laktasi menjadi semu (false), kadang tidak muncul puncak laktasi atau terjadi beberapa kali puncak laktasi selama periode laktasi.

Gambar 1 menunjukkan dengan bertambahnya hari laktasi (persistensi) terjadi rata-rata penurunan laju produksi susu secara lambat. Menurut Tucker (1985) bahwa selama laktasi kadar prolaktin akan tetap tinggi sebagai respon terhadap rangsang isapan anak domba yang berlangsung terus-menerus. Kadar prolaktin yang tinggi tersebur berdampak pada kerja organ otak dan ovarium. Di otak, prolaktin yang sampai di hipotamalus akan menghambat sekresi GnRH. Sedangkan kadar estrogen yang semula sangat tinggi selama persalinan karena sekresi dari plasenta akan mengalami penurunan setelah terlepasnya plasenta. Penurunan ini ternyata tidak mampu merangsang hipotamalus untuk mensekresi 
GnRH, hal ini mengisyaratkan adanya penurunan hipotamalus terhadap mekanisme umpan balik positif terhadap sekresi LH dan FSH dalam mengontrol pertumbuhan folikel dan ovulasi.Selama laktasi domba tidak menunjukkan estrus. Menurut Manalu (1999) bahwa dengan semakin bertambahnya umur anak akan menyebabkan penurunan produksi susu, karenasetelah anak domba mulai memakan rumput rangsangan yang diberikan ke kelenjar dan aktivitas sekretoris mensintesis air susu menjadi menurun.
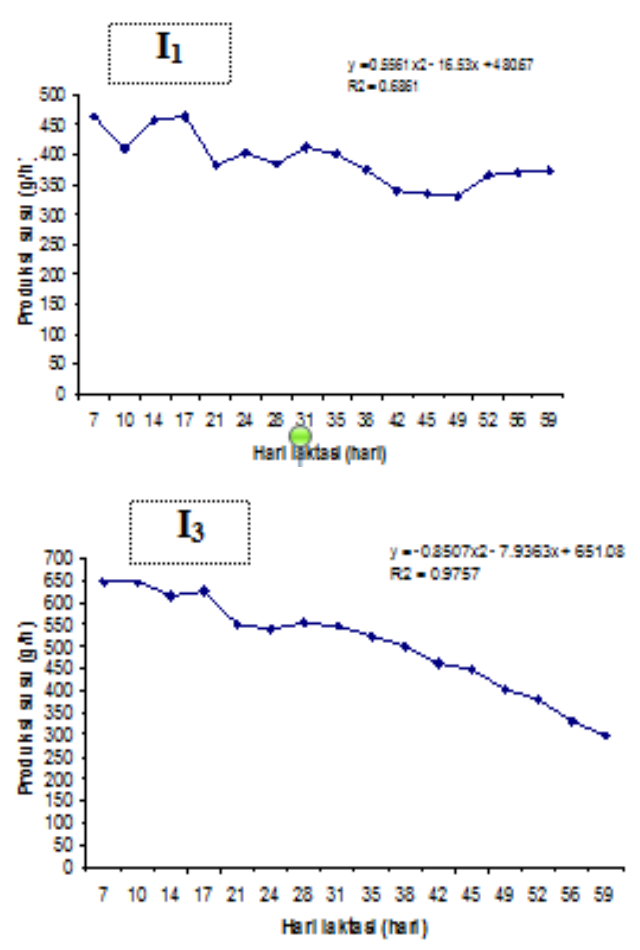
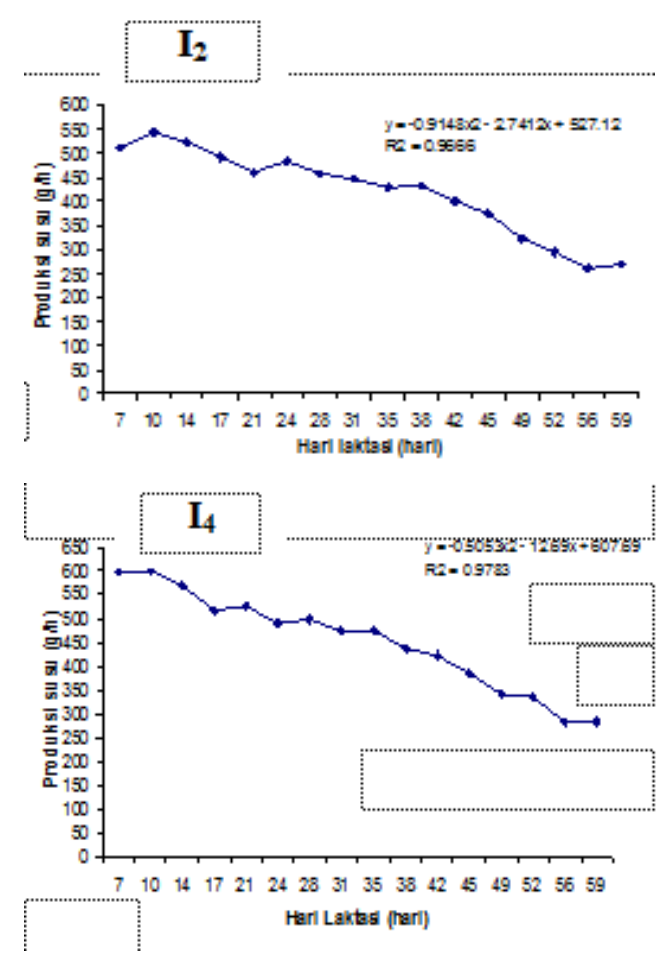

Gambar 1. Kurva produksi susu domba jonggol selama 59 hari laktasi berdasarkan umur induk

Pakan merupakan faktor yang sangat penting untuk pertumbuhan ambing selama kebuntingan, dimana akselerasi pertumbuhan ambing pada ternak domba terjadi pada fase akhir kebuntingan dan hanya sekitar 5\% terjadi pada awal laktasi (Lawrence dan fowler, 2002). Induk domba yang mengkonsumsi pakan dengan kualitas yang rendah terutama mingguminggu terakhir kebuntingan menyebabkan pertumbuhan ambing rendah dan menghasilkan ukuran ambing yang kecil, hal ini menyebabkan volume untuk menampung sel-sel skretori dan dapat menurunkan produksi susu 17-32\% (Treacher dan Caja, 2002). Selanjutnya, pemberian pakan yang cukup dan kualitas baik pada saat laktasi dapat meningkatkan proses metabolisme sintesa air susu, dimana kandungan nitrogen dan aktivitas 
enzim didalam retikulum, abomasum dan usus halus meningkat.

Suhu dan kelembapan lingkungan yang tinggi juga dapat meningkatkan produksi panas metabolisme di dalam tubuh, sehingga ternak akan berusaha melepaskan panas tubuh dengan meningkatkan konsumsi air dan mengurangi konsumsi pakan, kondisi ini dapat menurunkan produksi susu. Pada rata-rata suhu lingkungan sebesar $24^{\circ} \mathrm{C}$ tidak memberikan pengaruh yang nyata terhadap produksi susu, namun pada suhu lingkungan $34^{\circ} \mathrm{C}$ sangat nyata menurunkan produksi susu (Esmay, 1982). Laktasi harus berlanjut minimal sampai ketahap ketika anak domba dapat disapih dan dapat hidup dengan makanan sendiri. Produksi susu akan mengalami penurunan bersamaan dengan bertambahnya waktu laktasi (Pulina dan Nudda, 2004).

\section{KESIMPULAN}

Kurva produksi susu pada induk $\mathrm{I}_{1}$, $\mathrm{I}_{2}, \mathrm{I}_{3}$ dan $\mathrm{I}_{4}$ menunjukkan bahwa selama 16 minggu laktasi tidak menggambarakan kurva produksi susu yang normal dan puncak laktasi terjadi pada minggu kedua dan ketiga setelah melahirkan yang selanjutnya terus mengalami penurunan. Penurunan laju produksi susu pada induk $\mathrm{I}_{1}$ cenderung tidak stabil dibanding dengan induk yang lebih tua, hal ini menunjukkan bahwa produksi susu pada $\mathrm{I}_{1}$ diduga lebih rentan terhadap perubahan lingkungan terutama kondisi pakan dan suhu lingkungan.

\section{DAFTAR PUSTAKA}

Borlino, A. C, N.P.P Macciottaand G. Pulina. 2004. Mathematical Modelling of Milk Production Pattern in Dairy Sheep.In :Pulina, G, editor. Dairy Sheep Nutrition.CABI Publishing

Caja, G, A.A.K. Salama andX. Such. 2006. Omitting the dry off period negatively affects colostrums and milk yield in dairy goat. $J$ Dairy $S c i$ 89:4220-28.

Coleman, S.W and D.A Henry. 2002. Nutritive Value of Herbage.In: Freer, M, and H. Dove, editor. Sheep Nutrition.CABI Publishing.

Ensminger, M.E. 2002. Sheep and Goat Science. Interstate Publisher, Inc.

Esmay, L.M. 1982. Principles of Animal Enviroment. AVI Publishing Company, Inc. Wesport, Connecticut.

Goldsworthy, P.R, and N.M. Fisher. 1992. FisiologiTanamanBudidayaTropik. GadjahMadaUniversity Press.

Hardjowigeno, S. 2003. Ilmu Tanah. Akademika Presindo. Jakarta. 
Jarmuji. 2008. Identifikasi Produktifitas Induk Domba yang Digembalakan Sebagai Dasar Seleksi di Unit Pendidikan, Penelitian dan Peternakan Jonggol Institut Pertanian Bogor (UP3JIPB).Thesis.

Jarmuji. 2010. Pengaruh Umur Induk Terhadap Pertambahan Bobot Badan, Bobot Sapih dan Daya Hidup Anak Domba Jonggol (DET) Periode Prasapih. Jurnal Sain Peternakan Indonesia, Vol 5: 1 hal $34-42$

Lawrence, T.L.J and V.R. Fowler. 2002. Growth of Farm Animals. CABI Publishing.

Macciotta, N.P.P, Borlino, A.C andG. Pulina. 1999. Analysis of enviromentall effect of tes day milk yield of sarda dairy ewes. J Dairy Sci 77:1357-1542.

Manalu, W. 1999. FisiologiLaktasi [Diktat Kuliah]. Bogor: Program Pascasarjana, Bogor: Program PascaSarjanaFakultasKedokteranH ewan, InstitutPertanianBogor.

Mansyur. 2004. Interval pemotonganrumputBrachiariahumi dicola (Rendle) schwieek [Tesis]. Bogor: Program Pascasarjana, Institut Pertanian Bogor.
Minson, D.J. 1990. Forage In Ruminant Nutrition. San Diego. California Academi Press.

Pollott, G.E and E.Gootwine. 2004. Reproductive performance and milk production of assaf sheep in an intensif management system. $J$ Dairy Sci 87:3690-703.

Pulina, G and A. Nudda, 2004. Milk Production. In: Pullina G, editor. Dairy Sheep Nutrition. CABI Publishing.

Ruiz, R, L.M. Oreguei and M.Herrerot. 2000. Comparison of model for describing the lactation curve of laxta sheep andan análisisof factors affecting milk yield. J Dairy Sci $83: 2709-719$

Sumantri, C.,Einstiana, A., Salamena J.F dan I. Inounu.2007. Keragaan dan Hubungan Phylogenik antar Domba Lokal di Indonesia melalui Pendekatan Analisis Morfologi. JITV 12: $42-54$

Susetyo, S. 1980. Padang Pengembalaan. Diktat Kuliah, Fakultas Peternakan Institut Pertanian Bogor. Bogor.

Treacher, T.T and G.Caja. 2002. Nutrition during Lactation.In: Freer, $\mathrm{M}$ and $\mathrm{H}$ Dove, editor. Sheep Nutrition. CABI Publishing. 
Tucker, H.A. 1985. Endocrine and Neural Control of The Mammary Gland. In: Larson BL, editor. Laktation. The IowaStateUniversity Press/AMES.

[UP3J] Unit Pendidikan, Penelitian dan Peternakan Jonggol.2007. Data
Iklim di UP3J selama Periode 2007. Jonggol: Fakultas Peternakan. InstitutpertanianBogor. Whitehead, D.C. 2000. Nutrien Element in Grassland: Soil-Plant-Animal Relationship. Wallingford. $\mathrm{CAB}$ International Publishing. 